\title{
Forests as landscapes of social inequality: tropical forest cover and land distribution among shifting cultivators
}

\author{
Oliver T. Coomes ${ }^{1}$, Yoshito Takasaki $^{2}$ and Jeanine M. Rhemtulla ${ }^{3}$
}

\begin{abstract}
Can social inequality be seen imprinted in a forest landscape? We studied the relationship between land holding, land use, and inequality in a peasant community in the Peruvian Amazon where farmers practice swidden-fallow cultivation. Longitudinal data on land holding, land use, and land cover were gathered through field-level surveys $(\mathrm{n}=316)$ and household interviews $(\mathrm{n}=51)$ in 1994/1995 and 2007. Forest cover change between 1965 and 2007 was documented through interpretation of air photos and satellite imagery. We introduce the concept of "land use inequality" to capture differences across households in the distribution of forest fallowing and orchard raising as key land uses that affect household welfare and the sustainability of swidden-fallow agriculture. We find that land holding, land use, and forest cover distribution are correlated and that the forest today reflects social inequality a decade prior. Although initially land-poor households may catch up in terms of land holdings, their use and land cover remain impoverished. Differential land use investment through time links social inequality and forest cover. Implications are discussed for the study of forests as landscapes of inequality, the relationship between social inequality and forest composition, and the forest-poverty nexus.
\end{abstract}

Key Words: Amazonia; land inequality; land use and land cover change; path dependency; secondary forests

\section{INTRODUCTION}

One of the grand challenges in research on social-ecological systems is how to incorporate the social distribution of resource access into the study of sustainable use and management of natural resources and ecosystem services. The social distribution of resource access matters for sustainability in rural agrarian societies in at least three ways. First, resource access conditions how people use resources. For example, farmers with abundant land use their land more extensively, whereas those with small holdings use their land more intensively; as such, farm productivity can be inversely related to land holding (Boserup 1965, Berry and Cline 1979, Feder 1985, Barrett et al. 2010). Emerging work on land grabbing demonstrates how large-scale acquisitions influence deforestation rates and agricultural land uses (Davis et al. 2015, Rudel 2015). Second, resources are productive assets such that resource access equates to asset wealth, so that farmers with more land have a greater asset base to draw upon, diversify production, hedge risks taken, and self-insure than farmers with small land holdings (Bardhan 1984, Ellis 1993, Reardon and Vosti 1995, Ray 1998). Third, the income derived through resource use can be invested in improving access to resources and thus wealth acquisition, thereby changing in turn the social distribution of resource access (Ellis 2000, Tole 2004). As resource access is iteratively linked to how resources are used, we expect that sustainability outcomes would be related to how equally or unequally resources are distributed within society (de Janvry et al. 2001, Baland et al. 2006, Neumayer 2011, Lopes et al. 2015). As yet, few studies empirically explore the links between rural sustainability and social inequality.

In this paper we examine a key outcome of global concern-forest cover change in Amazonia - and social inequality among people who live in the rain forest. To date, research has proceeded on two productive but parallel fronts: one focusing on the drivers of tropical forest cover change (Turner et al. 2001, Geist and Lambin 2002, Lambin et al. 2003, Gibbs et al. 2010) and the other on forest use and social inequality among forest users (Cavendish 2000, Fisher 2004, Godoy et al. 2004, Angelsen et al. 2014). Studies of tropical forest cover change, combining satellite imagery and household surveys, have successfully identified the "signal" of economic structural change, specific economic policies (e.g., credit), migration and remittances, household demographics, and livelihood diversification in the forest landscape in Neotropical America (e.g., McCracken et al. 1999, Geoghegan et al. 2001, Walker 2003, VanWey et al. 2007, Turner 2010, Naughton-Treves et al. 2011). Such work reveals clearly that forests are not only impacted and transformed through use, but also that their composition is a reflection of underlying social and economic processes. At the same time, researchers have been studying social inequality among tropical forest groups, particularly those threatened by deforestation, displacement, and dispossession (Schmink and Wood 1992, Hecht and Cockburn 2010). A growing body of work points to significant income and asset inequality within the peasantry that has important implications for understanding rural poverty dynamics as well as forest use and landscapes (Reddy and Chakravarty 1999, Coomes et al. 2004, McSweeney 2004, Adams et al. 2013, Ribeiro Palacios et al. 2013, Angelsen et al. 2014). Despite advances on both fronts, research on forest change and research on social inequality in small-holder agriculture have yet to be joined explicitly to explore how forest cover may be related to inequality through time.

We examined the relationship between tropical forest cover and land inequality through a longitudinal study of forest land use in an Amazonian peasant community where people practice shifting cultivation (swidden-fallow agroforestry) and thereby have created over decades an anthropogenic secondary forest from a primary forest. In the tropical world, secondary forests now surpass primary forests in areal extent in many countries (FAO 2005), and they are important for agricultural and biological diversity as well as the provisioning of ecosystem services, including carbon storage, nutrient cycling, and water regulation

${ }^{1}$ Department of Geography, McGill University, ${ }^{2}$ Graduate School of Economics, University of Tokyo, ${ }^{3}$ Department of Forest \& Conservation Sciences, University of British Columbia 
(Brown and Lugo 1990, Chazdon et al. 2009, Padoch and PinedoVasquez 2010, Martin et al. 2013, Wandelli and Fearnside 2015). Our attention in studying social inequality focused upon land as the primary economic asset of peasant households, both in terms of the land holding and in how the land is used. This paper builds on a previous report that identifies land use poverty traps in the study community (see Coomes et al. 2011). Here, we examine inequality in both land size and land use over time, and the expression of land inequality in the forest landscape.

Land inequality and land use/cover outcomes: conceptual linkages Research to date on land use and asset poverty has focused on inequality in the distribution of land holdings by size among rural agrarian households, i.e., land size inequality (Bardhan 1984, Tole 2004, Carter and Barrett 2006). We argue that inequality exists not only in the size of land holdings but also, and relatedly, in how the land is used. We conceive of inequality in land use, i.e., "land use inequality," to be analogous to income inequality. Households may differ markedly in how income is earned, reflecting diversity in income sources and livelihood strategies; income inequality lies in the distribution of income across households. Similarly, households differ in how they use the land, reflecting diversity in land uses; land use inequality lies in the distribution of land uses across households. As such, land use diversity and inequality, though related, are distinct. Like income, different land uses have varied implications for welfare and sustainability, and so their distribution across households matters. Whereas income is measured at the level of household, land use is measured at the level of field (if households have multiple fields), and the distribution of land uses across households is assessed through household-level aggregation of land uses. Land use inequality is important in the present case study because households can be vulnerable to land use poverty traps whereby differences in land holding size foreclose opportunities for more profitable and sustainable land use (Coomes et al. 2011). To link forest cover change and social inequality, we focused on inequality in both land size and land use, and forest cover across households through time.

Central to our argument is the dynamic relationship between land holding size and land use/cover. In general, the amount of land held by households strongly conditions how they use the land; for example, land-richer households tend to use their land less intensively and may keep more forests than land-poorer households (D'Antona et al. 2006, Michalski et al. 2010, Coomes et al. 2011). We argue, however, that land use/cover may also diverge from land holdings because of path dependence, particularly in fallow-based shifting cultivation systems where time is needed for fallow trees and orchards to mature. Consider two cases, one in which land accumulation trajectories diverge (A) and the other in which land holdings converge through time (B; Fig. 1). Land covers include crop, orchards, and secondary forest fallows. The age or duration of a fallow or orchard is a proxy for tree stocks. In the first case, land use/cover differences can be explained primarily by differences in land holdings that can be traced back to the initial endowment of land holdings. In the second case, differences in land use/cover reflect the culmination of earlier land use investment decisions shaped by the initial endowment of land holdings. Households with a small initial endowment of land holdings could not, at the time, afford to invest in orchards or long-term fallows and even though today they hold sufficient land, time has passed that cannot be recovered and the opportunity to invest in trees was forgone. In this way, we expect the composition and distribution of forest cover today to be a reflection of past differences in initial endowments of land holdings.

Fig. 1. Household land accumulation and land use/cover outcomes for divergent and convergent household land accumulation trajectories (C: crop; O: orchard; F: fallow forest).

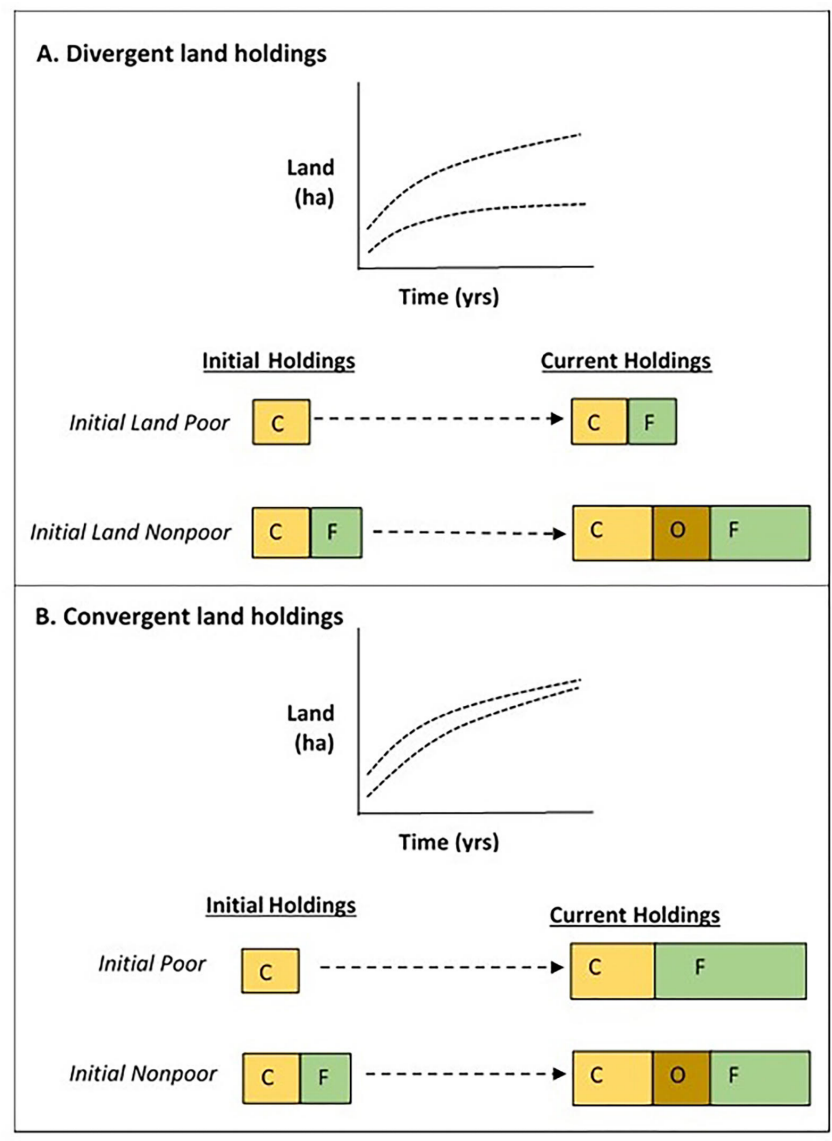

\section{STUDY AREA}

The study community of San Jose (pseudonym) is situated on a Tertiary bluff overlooking the Amazon River in northeastern Peru, one day's riverboat travel from Iquitos, the largest city in the Peruvian Amazon. Community lands ( 886 ha) are covered by secondary forest fallows of varying ages, orchards, and swiddens. In 2007, San Jose comprised 70 households (340 individuals) of nuclear peasant families (ribereños: riverine people; Hiraoka 1992, Chibnik 1994), many of whom have lived for several generations in the community, practicing market-oriented swidden-fallow agroforestry, annual cultivation of the Amazon floodplain, fishing and nontimber forest product extraction, and rearing chickens and pigs (Coomes et al. 2011). Founded as an agricultural estate in 1865 , the community became independent in 1971 with estate dissolution under the Peruvian Agrarian Reform, and lands were turned over then to resident workers. 
Since 1981, the community has been enclosed on all sides by other communities and river courses, such that no new forest land is available to the community; and by 2007, all land apt for agriculture within community boundaries had been claimed by residents. Outmigration since the 1990s has offset natural increase in the community and the population of San Jose has since remained relatively constant.

Two forms of agriculture are practiced locally: swidden-fallow agroforestry and to a lesser extent, floodplain cropping. Swiddenfallow agroforestry is practiced on the upland (terra firme) upon which the community is situated, some $20-30 \mathrm{~m}$ above the floodplain of the Amazon River, and on a paleo-terrace, $3-4 \mathrm{~km}$ inland from the settlement. Upland soils are deeply weathered and acidic Ultisols. A forested plot of up to 1 ha is cleared using machetes and axes, burned, and cultivated under succession of annual and perennial crops (manioc, pineapple, and orchard fruit), and then left to regenerate as a secondary forest fallow for 7-12 years or more. Umarí (Pouraqueiba sericea) is the primary orchard crop, which produces a marketable fruit for up to 25 years (Coomes and Burt 1997). Nontimber forest products, particularly chambira palm fiber (Astrocaryum chambira), are extracted from forest fallows (Coomes 2004). Charcoal is made from wood cut from forest fallows and orchards at the beginning of a new cycle of cultivation (Coomes and Burt 2001). On the Amazon floodplain, farmers annually cultivate manioc and cereals (rice, beans, maize, and cowpea) on the fertile but risky, flood-prone Entisols. Agricultural tasks are undertaken using in-house labor and cooperative work parties with kinfolk. No agricultural credit or technical assistance is available. Agricultural produce is consumed locally or sent by riverboat to markets for sale in Iquitos.

Residents of San Jose are generally poor in both income and assets. In 2007, the median household income was $\$ 3895$ or about $\$ 2.13 /$ person per day, similar to the daily wage rate of $\$ 2-\$ 2.5 /$ day (Coomes et al. 2011). Primary income sources for the mean income portfolio were agriculture $(22 \%)$, charcoal production (26\%), fishing (38\%), and other (14\%; Appendix 1, Table A1). The principal productive asset is land, with a mean holding of 7.7 ha per household (8.5 fields) and a range of 0.5-19.2 ha (2-17 fields). Plots of community land are allocated for use by village authorities and held in usufruct by households following clearing and planting as long as they remain in the community, i.e., through cropping and fallowing phases. Households cannot buy or sell land; land is transferred by gifting and inheritance only, along family and kinfolk lines. The mean land portfolio is dominated by upland plots (63\%), followed by Amazon floodplain $(24 \%)$ and terrace $(12 \%)$. Among upland holdings, the mean household has $63 \%$ of land in forest fallow, $25 \%$ in orchard, and $12 \%$ in crop. The mean age of orchards and forest fallows is 9.3 years and 14.7 years, respectively, across households. Orchards and forest fallows provide a stream of income, and the stock of trees is considered by households to be a productive asset. Over time, incomes have risen in the community as households rely increasingly on charcoal production and fishing to offset land scarcity, particularly for newly formed households (see Table A1). Today, land is relatively unequally distributed in the community, with one quarter of households holding $46 \%$ of the land, and land inequality is a source of local social tension. Our previous work suggests the presence of a land use poverty trap whereby small initial land holdings force households to focus production on subsistence cropping and short fallow periods, trapping them in low agricultural productivity (Coomes et al. 2011; S. Wood, J. Rhemtulla and O. T. Coomes, unpublished manuscript). Residents have resorted to using biochar to raise land productivity (Miltner and Coomes 2015, Coomes and Miltner 2016).

\section{METHODS}

\section{Data collection}

This study drew on data gathered in 1994/1995 and 2007 and used in Coomes et al. (2011). In 1994, a structured questionnaire was administered to all households practicing swidden-fallow agroforestry on household demographics, production, and assets. At each field site, field size, cover, history, and mode of acquisition (e.g., claimed, cleared, transferred) were recorded. Abandoned fields and fields transferred to others were included. In 2007, the structured questionnaire was readministered; all fields on the upland and terrace were mapped using a Global Positioning System; and field cover, history, and modes of acquisition were updated. The 1994 and 2007 databases were joined at the field level, based on location, size, field cover, and acquisition history. All live births, deaths, and departures from each household were also recorded, allowing the tracking of household size and composition through time as well as household arrivals and departures. The final data set comprised 51 households and 316 fields for the period 1975 to 2007.

\section{Land cover and use}

Stereoscopic aerial photographs for 1965, 1972, 1978, and 1991 (1:10 to 1:40,000, Servicio Aerofotográfico Nacional) and a highresolution satellite image (EROS-B; $0.7 \mathrm{~m}$ Panchromatic, July 31, 2007) were acquired for assessment of changes in land cover. Ground control points collected in the field were used for georeferencing of images. Air photos were manually interpreted with a stereoscope, and polygon boundaries were then digitized onscreen in ArcGIS. Field histories were constructed with respondents while standing in their fields, beginning with the current use/cover and working back through time. Because swidden-fallow agroforestry follows a "script" or programmatic sequence with few decisions points, each with a small set of crop and fallow options (see Coomes and Burt 1997), respondents were able to report field cover histories annually for long periods, in some cases back to the 1950s. This approach had been less successful in the dynamic floodplain and more remote terrace, so our analyses focused on upland fields where most swidden-fallow agroforestry is practiced. Comparisons of land cover data from field histories and aerial photographs matched reasonably well. Household land cover data included fields with incomplete land cover history, i.e., fields with unknown land cover at some point of time; these fields were excluded from analysis. To test for attrition bias, we repeated all analyses using land cover information from the air photos for unknown land cover in corresponding years. Because the results were qualitatively the same as those presented here, attrition bias is unlikely to be a major concern. The duration of upland land cover included early years when a field may have been owned by households not in the sample (e.g., defunct ones). If field cover data were different from the air photos, the field was excluded from analysis. To assess the distribution of field-level measures of land use across households, we used weighted household means of land cover duration using 
Fig. 2. Land types and land cover, San Jose, 1965 and 2007.
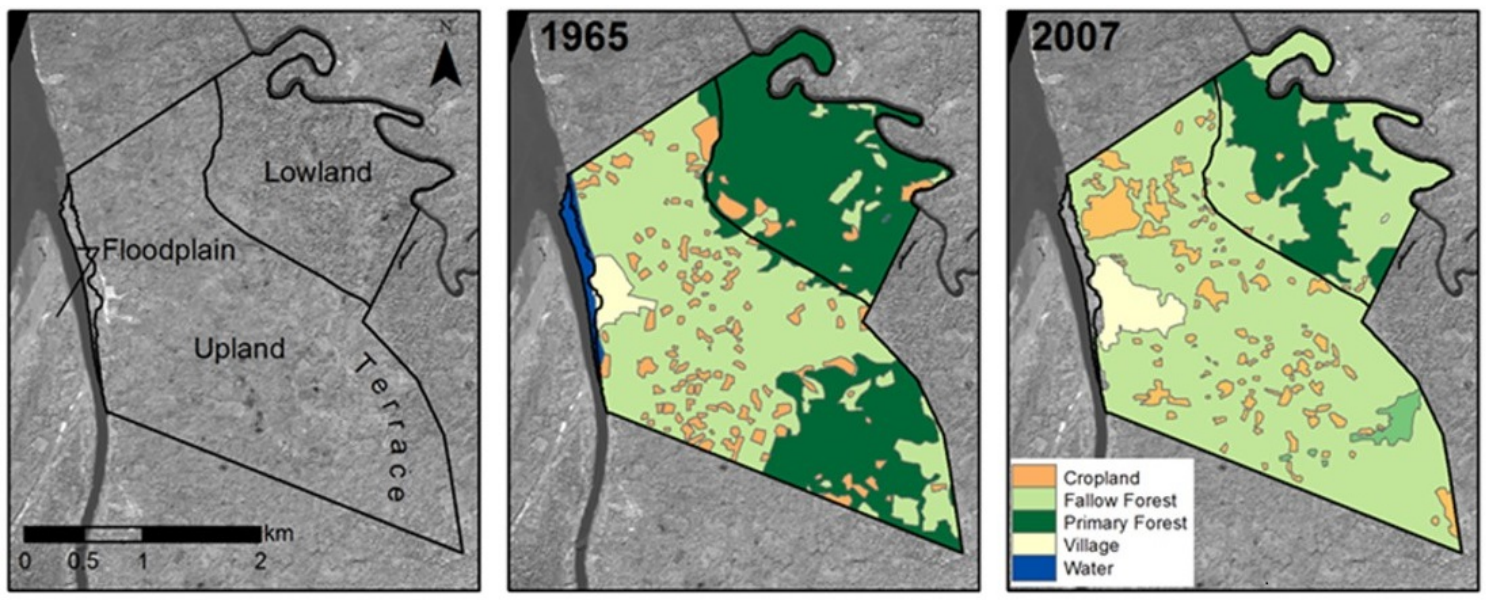

field size as weights. In this way, the contributions of duration in fields reflected their size.

\section{Land holding and inequality}

Household land holding data included all fields, including those with unknown land cover. Initial land holdings were calculated at household inception. The mean number of households in each year was 31 (range, 12-48) in 1980-2007 and 39 (range, 28-48) in 1991-2007. The analysis of mode of land acquisition captured both original acquisition and later land transfer. Because the mode and year of acquisition were known for each field, we could aggregate across all fields in a given historical period (e.g., by year) to know what portion of land was acquired by claiming or gifting/ inheritance mode. Our main inequality measure across households was the Gini coefficient, which can take a value from 0 through 1. All results of alternative inequality measures, coefficient of variation and Theil index, were qualitatively the same as those of the Gini coefficient. To calculate Gini coefficients for household-weighted means of orchard age and fallow duration (field size as weights), we did not reweight them by household land holding size. If we did this reweighting, the contributions of age and duration of households to the Gini coefficients would have reflected their land holding size, thus mixing land size and land use inequality in the same measure. For comparison, we also considered reweighted age and duration to calculate Gini coefficients, finding results similar to the unweighted results reported here.

\section{RESULTS}

\section{Land cover change}

Land cover in San Jose has changed significantly over the past 40 years. Households have steadily transformed primary forest cover to cropland, orchards, and secondary forest fallows, especially on the upland, which represents $68 \%$ of community land. Analysis of aerial photographs showed that between 1965 and 2007, primary forest decreased from 122 ha ( $12 \%$ of upland area) to near elimination by the mid-1990s; by 2007 , no primary forest was found on the upland and only degraded primary forest remained on the paleo-terrace (Fig. 2). In contrast, the total area in secondary forest fallows and orchards increased steadily from
387 ha in 1965 to 484 ha in 2007 to occupy $80 \%$ of the upland. Opened/cleared land (i.e., swiddens, former pasture, open shrub) also increased over time but at a slower rate than secondary forest. Our analyses focused on land inequality and land cover change on the upland since the era of community enclosure (c. 1981).

Historical household data on field holdings indicate that whereas secondary forest fallow area expanded from 1981 to 2007, the proportion of area in orchards decreased (about $40 \%$ to $17 \%$ ); the share in annual and other perennial crops rose from $6 \%$ to $11 \%$. Between the 1980 s and 2000 s, the size of mean land holdings fell from 7.1 ha to 4.8 ha, driven by a decrease in fallow field size from 1.8 ha to 1.0 ha and orchard field size from 1.6 ha to 0.5 ha; crop field size remained stable.

\section{Land size distribution}

The distribution of land holdings among households changed markedly since community enclosure. In the late 1970s, the Gini coefficient of total land holdings and upland land holdings was about 0.35 (Fig. 3). At this time, the top $20 \%$ of households held about $32 \%$ of the land. When the community was enclosed in 1981, inequality in land holding fell sharply, particularly for total land holdings (Gini: 0.25), as households rushed to claim fertile lands on the distant paleo-terrace (initially land poorer households) and the risky Amazon floodplain (initially richer households). During this period, the last of the remaining primary forest was degraded and/or cleared. Land size inequality then rose to a peak in 1992 (total land Gini: 0.45 ) when the top 20\% of households held $43 \%$ of the land, before falling steadily over the next 15 years to levels similar to those in the late 1970s. During the period of 1980 to 2007 , the mode of land acquisition changed from land claiming through forest clearing to acquisition through gifting/inheritance: In 1981, more than $60 \%$ of land had been acquired by claiming; by 1991, claiming and gifting were at par; and by 2007, gifting surpassed claiming. According to Gini decomposition by source (Lerman and Yitzhaki 1985, Stark et al. 1986), the general shift from claiming to land transfers is reflected in the share of inequality attributable to each mode of acquisition: In the early $1980 \mathrm{~s}$, about $70 \%$ of upland inequality was found in claimed lands, whereas by 2007 , more than $60 \%$ of upland inequality was found in transferred land (Fig. A1.1, where the 
shares of claimed and gifted lands do not add up to one in some years because other modes of acquisition [purchase and lease] and unknown mode of acquisition, which are very uncommon, are not reported). Contributing to this transition were transfers of forest fallows and orchards: Gifting surpassed claiming much earlier for fallows than orchards (1991 vs. 2001) and more completely (Fig. A1.2). Falling inequality since 1992 was thus the result of intergenerational transfers of land between land-richer parents and land-poorer adult children and kinfolk. Land diversification and inheritance enabled initially land-poor households to acquire land and essentially catch up in terms of total land holding with initially land-nonpoor households, reducing land size inequality in the community.

Fig. 3. Land size inequality and upland land cover change, San Jose, 1980-2007.

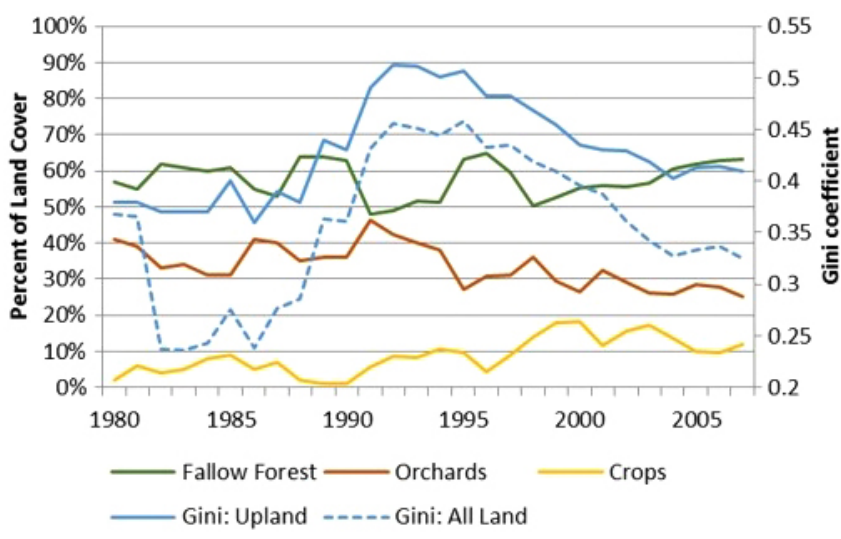

\section{Land use distribution}

To assess how inequality in land use changed, we focused on two proxy measures, orchard age and fallow duration, and their distributions across households through time. Both measures are proxies for land use because land use is essentially an investment "flow" (in this case, in trees), whereas tree age is a stock measure. Orchard age is related directly to productivity, because umarí requires six years to bear fruit and production peaks between 10 and 20 years. Umarí can be an important source of cash income for households at a time of year when alternate income sources are few, and orchards can serve as effectively as fallows for restoration of soil fertility and biomass, without hindering future biodiversity potential (Wood et al. 2016). Fallow duration or age is also related to rebuilding of biomass, soil fertility, and elimination of weeds, and the benefits of fallowing rise sharply with time and then taper off (Ruthenberg 1980, Uhl and Jordan 1984, Martin et al. 2013). Like orchards, forest fallows also provide economic goods, i.e., nontimber forest products such as chambira fiber, round wood, fruit, and medicinals, which require time to grow and mature in the secondary forest. Most farmers interviewed reported that forest fallows of 10-15 years were sufficient to be recut for cultivation.

During the 1990s and 2000s, when land size inequality peaked and then fell, the mean age of orchards and forest fallows across households with any orchard and any fallow, respectively, remained relatively unchanged (orchards: 9.7 years vs. 10.0 years; fallows: 10.1 years vs. 9.6 years), but the distribution of both changed notably (the analysis covers 1991 and later because the number of household observations is small before 1991). Between 1991 and 2001, the Gini coefficients of orchard age and fallow duration tracked closely, indicating decreasing, then sharply rising, inequality in the late 1990s. Inequality in orchard and fallow ages diverged in 2002, and by 2007, inequality in fallow duration (Gini: 0.44) was higher than inequality in orchard age (Gini: 0.31; Fig. 4). Importantly, the peaks of inequality for each occurred in different years: Orchard age inequality peaked first, in 1998, and inequality in fallow age crested later, in 2004. As such, forest cover had become more unequal across households in terms of tree stand ages.

\section{Land inequality and land cover change}

When land size inequality and land use inequality were compared, we found a shift in inequality from land size to land use (Fig. 4). Whereas inequality in land holding peaked in 1992, inequality peaked 6 years later in orchard age and 12 years later in fallow age. Such lags are consistent with the maturation times required for orchards and forest fallows, respectively. To visualize the shift in land use inequality, we constructed tree maps (Johnson and Shneiderman 1991) that show how upland land holdings by household and land cover age evolve through time. In this environment, where crop fields, fallows, and orchards are dispersed over the landscape, it is difficult to discern patterns of change using land cover maps. In the tree maps, fields are compiled by size and type, showing the relative importance of different land covers in a given year and allowing us to see changes in land inequality over time.

Fig. 4. Shift from land size to land use inequality on upland, San Jose, 1991-2007.

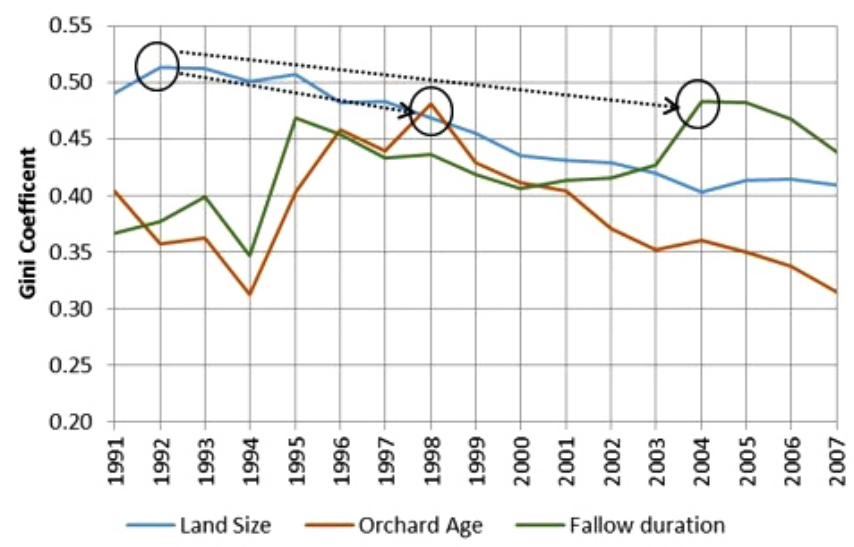

Comparison of the tree maps for 1992, at the peak of land size inequality, and 2007 using fields with known land cover at both dates illustrates how holdings (rectangles with bold lines) have become more equally distributed among households while inequality in fallow age has clearly risen (Fig. 5). Changes in the age distribution are evident by comparing colors rather than field size (rectangles with narrow lines) across households; in particular, the number of households with relatively young fallow 
Fig. 5. Tree maps of land cover by household holdings, San Jose, in 1992 and 2007. Bold lines enclose the fields (narrow lines) held by an individual household. Note that because the total land holdings increase through time, field sizes are only comparable within each tree map. Although field sizes are not directly comparable between dates, field sizes do decline through time.

\section{2}

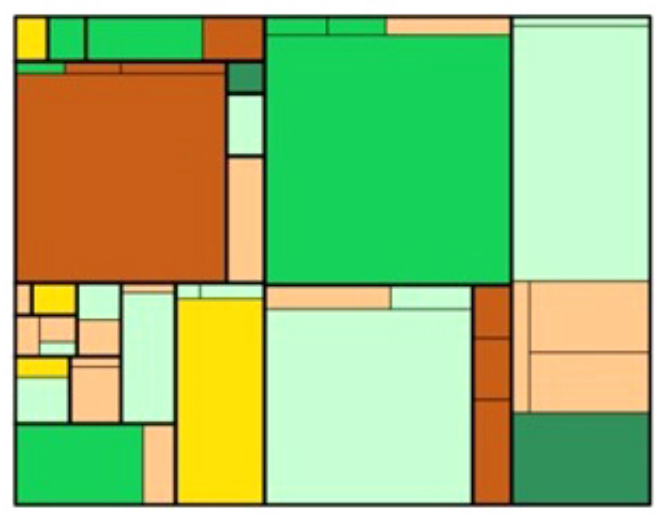

2007

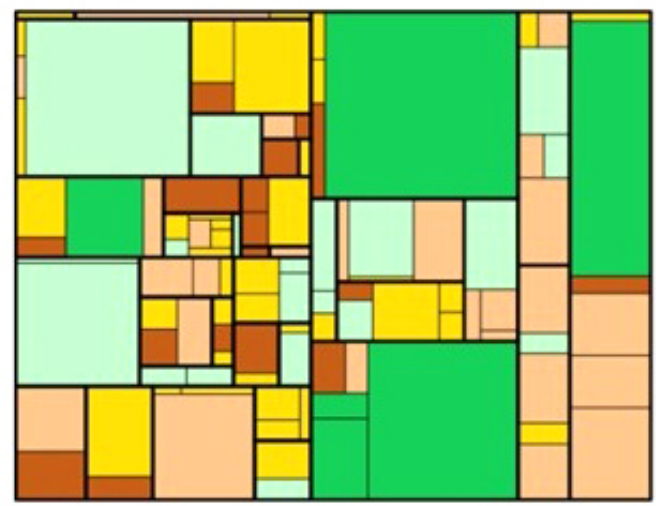

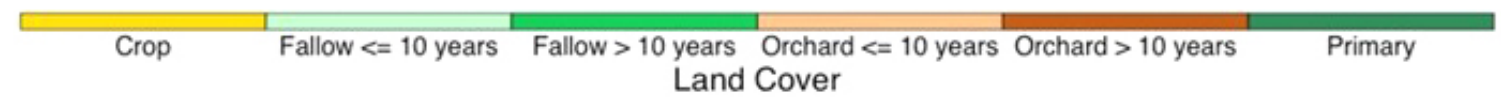

fields (10 years or less) greatly increased over time, although the number of households with relatively old fallows (more than 10 years) decreased slightly. Increased fragmentation of land holdings is also evident over time, because land is transferred via gifting/inheritance, although the number of households (fields) per se does not influence across-household inequality as measured by the Gini coefficient.

Land transfers were important, along with earlier claiming of paleo-terrace land, in allowing households that begin with little land to catch up with households with a large initial land endowment. By 2007, the land holdings of initially land-poor households were no longer significantly smaller than those of initially land-nonpoor households at a $5 \%$ significance level (their mean holdings in 2007 were 6.5 ha and 8.8 ha, respectively; Fig. A1.3). Still, these two groups use their land differently, despite having today not dissimilar sizes of land holdings, with distinct land cover outcomes. When orchard age and fallow duration are compared between initially land-poor and land-nonpoor households, as probability density functions, we found that initially nonpoor households have "healthy" orchard ages (8 years) and fallow ages (20 years; Fig. A1.4; see Coomes et al. 2011 for details of this analysis). In contrast, initially poor households have very old and very young orchards ( 28 years; 4 years; outside the productive life of umarí), as well as forest fallows that are too short in duration to be recut (5 years). Indeed, with orchards much older than their fallows, the initially poor households appear to be using orchards as fallows in place of secondary forests. In addition, the species composition of forest fallows of these two groups is significantly different. Households that began with more land have fallows with higher species richness and a greater number of climax species and singletons, controlling for fallow age (see Wood 2014). Thus, although initially poor households have caught up in terms of land holding, the land cover/use on their holdings remains distinct. Households in San Jose differ markedly in land cover/use today despite holding similar areas of land: The composition and distribution of forest cover today reflect past differences in initial household endowments of land.

\section{DISCUSSION AND CONCLUSION}

Four principal findings emerge from this study of land cover change and land inequality in an Amazonian peasant community. First, we found that tropical forest cover is related to social inequality over time. We identified one mechanism by which this occurs: differential land use practices and investment choices on the land by farmers. In shifting cultivation systems, farmers transform small dispersed stands of primary or secondary forest through the cropping cycle into plots of secondary forest fallows and agroforests, e.g., orchards, timber stands, cacao, rubber. In doing so, they create an extensive mosaic of anthropogenic forest around their communities. Because this forest mosaic is an agglomeration of all individual land holdings, the distribution of land holding among farmers, measured as inequality, will be expressed in the composition of the forest mosaic. Dynamic land use decisions reshape the forest landscape; changes in the extent and type of forest cover, in turn, condition the acquisition, accumulation, and use of land. The cumulative outcome of this generation's land use decisions determines the initial forest cover for the next generation, and in this way, forest cover and social inequality are related.

Second, two distinct types of land inequality are important for determining forest extent and composition: land holding size and land use. To date, research in land use/cover change has focused on the role of land holding size and on individual holdings and use rather than the distribution of land size holdings and land 
use among farmers. Generally, farmers with similar land size holdings are expected to use their land similarly, other things being equal. We found, however, that land size holdings and land use are not coincident in shifting cultivation systems where farmers invest in forests, fallows, or perennial tree crops. Relative inequality in land holdings and land use is likely to be contingent on community-wide land availability, because differences among farming households in agricultural practices shift from being about how much land they held before community closure to how they use it in post enclosure, when new land is scarce; and how they use their land, in turn, directly determines forest cover.

Third, path dependency is strongly evident in shifting cultivation systems. Compared with other farming systems, shifting cultivation, where land markets are typically absent or weak, is considered to be less path dependent as far as farmers can clear forest for new land. Indeed, even in our study community, which experienced enclosure, a land size (poverty) trap was avoided through land transfers and land holding diversification (Coomes et al. 2011). Nonetheless, path dependency is strong in shifting cultivation because of the time investment in trees, either directly (orchards) or indirectly (secondary forest fallows). The shift in peak of inequality from land holding to orchard age took six years and that from orchard age to fallow duration took another six years, closely matching the time required to obtain returns from the investment in orchards and fallows, which is suggestive evidence of path dependency built in the forest through land use. Although the community avoided a land size poverty trap through inequality-reducing land transfers and diversification of land holdings, a land use poverty trap persisted (Coomes et al. 2011) as a direct result of path dependency in fallow-based farming.

Finally, the current tropical forest cover where swidden-fallow agriculture is practiced reflects land inequality in years past. Trees, whether planted or regrowing in forest fallows, represent an important investment by land owners that take years to mature beyond the initial decision to invest in them. In our case, current land use and land cover reflect inequality in land size holding about a decade before, reflecting the maturation time of fallows and orchards. The implications of this time lag between forest cover and land inequality are threefold. First, households that began with only a small amount of land may be able to catch up with those households that began with more land, but their use of the land will be distinct because their decisions in the past when they were land poor, i.e., to invest little in forests and orchards, cannot be undone and they will remain today relatively poor in productive anthropogenic forests. As such, decisions made in the past echo through the distribution of land uses and are expressed later in the forest mosaic. Second, the path dependency imposed by the long maturation time of trees and fallows means that forest mosaics under shifting cultivation may be relatively "stickier,"i.e., less prone to rapid change, than under other farming systems. The forest mosaic will change with changing land distribution and use, but relatively slowly because of the inherent lag in the system. This inertia is advantageous in the efforts to conserve biodiversity and ecosystem services that flow from swidden-fallow agroforestry systems. Finally, policies aimed at redressing social inequality will have long-term effects on forest cover, either indirectly through redistribution via land reform or directly through land use change promotion, e.g., subsidized tree planting, payment for ecosystem services. Although land redistribution among farmers can reduce inequality in land holding by providing the land poor with more land, and land use incentives can promote perennial crops among the poor, neither set of policies will enable farmers to make up for lost time and remedy the imprint of poverty in the forest. Forest mosaics can thus be seen as landscapes of inequality where the social distribution of land wealth in the past is reflected in the type and age of stands that comprise the forest today. Future research should address the economic and ecological consequences of related differences in forest composition, sustainability outcomes, and the pathways by which forests may coevolve with social inequality.

Responses to this article can be read online at: http://www.ecologyandsociety.org/issues/responses. $\mathrm{php} / 8684$

\section{Acknowledgments:}

The people of San Jose are gratefully acknowledged for their generous collaboration that made this project possible. Field assistance in interviewing and gathering other field data, logistic support, and community relations were provided by Graeme Burt and Carlos Rengifo Upiachihua. An earlier version of this paper was presented at the GLP Open Science Meeting, Berlin, Germany, on March 19, 2014. The authors are grateful to two reviewers and the editors for their insightful and helpful comments. Grant support was provided by the Social Science and Humanities Research Council of Canada, National Science and Engineering Research Council of Canada, McGill University, and the Japan Society for the Promotion of Science.

\section{LITERATURE CITED}

Adams, C., L. Chamlian Munari, N. Van Vliet, R. S. Sereni Murrieta, B. A. Piperata, F. Futemma, N. Novaes Pedroso, Jr., C. Santos Taqueda, M. Abrahão Crevelaro, and V. L. SpressolaPrado. 2013. Diversifying incomes and losing landscape complexity in Quilombola shifting cultivation communities of the Atlantic rainforest (Brazil). Human Ecology 41:119-137. http:// dx.doi.org/10.1007/s10745-012-9529-9

Angelsen, A., P. Jagger, R. Babigumira, B. Belcher, N. J. Hogarth, S. Bauch, J. Börner, C. Smith-Hall, and S. Wunder. 2014 Environmental income and rural livelihoods: a globalcomparative analysis. World Development 64:S12-S28. http://dx. doi.org/10.1016/j.worlddev.2014.03.006

Baland, J.-M., P. Bardhan, and S. Bowles. 2006. Inequality, cooperation, and environmental sustainability. Princeton University Press, Princeton, New Jersey, USA.

Bardhan, P. 1984. Land, labor, and rural poverty. Columbia University Press, New York, New York, USA.

Barrett, C. B., M. F. Bellemare, and J. Y. Hou. 2010. Reconsidering conventional explanations of the inverse productivity-size relationship. World Development 38(1):88-97. http://dx.doi. org/10.1016/j.worlddev.2009.06.002 
Berry, R. A., and W. R. Cline. 1979. Agrarian structure and productivity in developing countries: a study prepared for the International Labour Office within the framework of the World Employment Programme. Johns Hopkins University Press, Baltimore, Maryland, USA.

Boserup, E. 1965. The conditions of agricultural growth: the economics of agrarian change under population pressure. Aldine, New York, New York, USA.

Brown, S., and A. E. Lugo. 1990. Tropical secondary forests. Journal of Tropical Ecology 6:1-32. http://dx.doi.org/10.1017/ S0266467400003989

Carter, M. R., and C. B. Barrett. 2006. The economics of poverty traps and persistent poverty: an asset-based approach. Journal of Development Studies 42:178-199. http://dx.doi.org/10.1080/0022$\underline{0380500405261}$

Cavendish, W. 2000. Empirical regularities in the povertyenvironment relationship of rural households: evidence from Zimbabwe. World Development 28(11):1979-2003. http://dx.doi. org/10.1016/s0305-750x(00)00066-8

Chazdon, R. L., C. A. Peres, D. Dent, D. Sheil, A. E. Lugo, D. Lamb, N. E. Stork, and S. E. Miller. 2009. The potential for species conservation in tropical secondary forests. Conservation Biology 23:1406-1417. http://dx.doi.org/10.1111/j.1523-1739.2009.01338. $\underline{\mathrm{x}}$

Chibnik, M. 1994. Risky rivers: the economics and politics of floodplain farming in Amazonia. University of Arizona Press, Tucson, Arizona, USA.

Coomes, O. T. 2004. Rain forest 'conservation-through-use'? Chambira palm fibre extraction and handicraft production in a land-constrained community, Peruvian Amazon. Biodiversity \& Conservation 13:351-360. http://dx.doi.org/10.1023/B:

BIOC.0000006503.90980.e8

Coomes, O. T., B. L. Barham, and Y. Takasaki. 2004. Targeting conservation-development initiatives in tropical forests: insights from analyses of rain forest use and economic reliance among Amazonian peasants. Ecological Economics 51:47-64. http://dx. doi.org/10.1016/j.ecolecon.2004.04.004

Coomes, O. T., and G. J. Burt. 1997. Indigenous market-oriented agroforestry: dissecting local diversity in western Amazonia. Agroforestry Systems 37:27-44. http://dx.doi.org/10.1023/ A: 1005834816188

Coomes, O. T., and G. J. Burt. 2001. Peasant charcoal production in the Peruvian Amazon: rainforest use and economic reliance. Forest Ecology and Management 140:39-50. http://dx.doi. org/10.1016/S0378-1127(00)00274-7

Coomes, O. T., and B. C. Miltner. 2016. Indigenous charcoal and biochar production: potential for soil improvement under shifting cultivation systems. Land Degradation \& Development http://dx. doi.org/10.1002/1dr.2500

Coomes, O. T., Y. Takasaki, and J. Rhemtulla. 2011. Land-use poverty traps identified in shifting cultivation systems shape longterm tropical forest cover. Proceedings of the National Academy of Sciences of the United States of America 108(34):13925-13930. http://dx.doi.org/10.1073/pnas.1012973108
D’Antona, Á. O., L. K. VanWey, and C. M. Hayashi. 2006. Property size and land cover change in the Brazilian Amazon. Population and Environment 27:373-396. http://dx.doi.org/10.1007/ s11111-006-0031-4

Davis, K. F., K. Yu, M. C. Rulli, L. Pichdara, and P. D’Odorico. 2015. Accelerated deforestation driven by large-scale land acquisitions in Cambodia. Nature Geosciences 8:772-776. http:// dx.doi.org/10.1038/ngeo2540

de Janvry, A., G. Gordillo, E. Sadoulet, and J.-P. Platteau, editors. 2001. Access to land, rural poverty, and public action. Oxford University Press, Oxford, UK. http://dx.doi.org/10.1093/acprof: oso/9780199242177.001.0001

Ellis, F. 1993. Peasant economics. Farm households in agrarian development. Wye Studies in Agricultural and Rural Development. Second Edition. Cambridge University Press, New York, New York, USA.

Ellis, F. 2000. Rural livelihoods and diversity in developing countries. Oxford University Press, New York, New York, USA.

Feder, G. 1985. The relationship between farm size and farm productivity: the role of family labor, supervision and credit constraints. Journal of Development Economics 18(2-3):197-313. http://dx.doi.org/10.1016/0304-3878(85)90059-8

Fisher, M. 2004. Household welfare and forest dependence in southern Malawi. Environment and Development Economics 9 (1):135-154. http://dx.doi.org/10.1017/s1355770x03001219

Food and Agricultural Organization (FAO). 2005. State of the world's forests. FAO, Rome, Italy.

Geist, H. J., and E. F. Lambin. 2002. Proximate causes and underlying driving forces of tropical deforestation. BioScience 52 (2):143-150. http://dx.doi.org/10.1641/0006-3568(2002)052[0143: pcaudf]2.0.co;2

Geoghegan, J., S. C. Villar, P. Klepeis, P. M. Mendoza, Y. OgnevaHimmelberger, R. R. Chowdhury, B. L. Turner, II, and C. Vance. 2001. Modeling tropical deforestation in the southern Yucatán peninsular region: comparing survey and satellite data. Agriculture, Ecosystems and Environment 85(1-3):25-46. http://dx. doi.org/10.1016/s0167-8809(01)00201-8

Gibbs, H. K., A. S. Ruesch, F. Achard, M. K. Clayton, P. Holmgren, N. Ramankutty, and J. A. Foley. 2010. Tropical forests were the primary sources of new agricultural land in the $1980 \mathrm{~s}$ and 1990s. Proceedings of the National Academy of Sciences of the United States of America 107(38):16732-16737. http://dx.doi. org/10.1073/pnas.0910275107

Godoy, R. A., M. Gurven, E. Byron, V. Reyes-García, J. Keough, V. Vadez, D. Wilkie, W. R. Leonard, L. Apaza, T. Huanca, and E. Pérez. 2004. Do markets worsen economic inequalities? Kuznets in the bush. Human Ecology 32(3):339-364. http://dx.doi. org/10.1023/b:huec.0000028085.47707.08

Hecht, S. B., and A. Cockburn. 2010. The fate of the forest. Developers, destroyers, and defenders of the Amazon. University of Chicago Press, Chicago, Illinois, USA. http://dx.doi. org/10.7208/chicago/9780226322735.001.0001

Hiraoka, M. 1992. Caboclo and ribereño resource management in Amazonia: a review. Pages 134-157 in K. H. Redford and C. 
Padoch, editors. Conservation of neotropical forests: working from traditional resource use. Columbia University Press, New York, New York, USA.

Johnson, B., and B. Shneiderman. 1991. Tree-maps: a space-filling approach to the visualization of hierarchical structures. Pages 284-291 in Proceedings of the 2nd Conference on Visualization' 91. IEEE, New York, New York, USA. http://dx.doi.org/10.1109/ visual.1991.175815

Lambin, E. F., H. J. Geist, and E. Lepers. 2003. Dynamics of landuse and land-cover change in tropical regions. Annual Review of Environment and Resources 28:205-241. http://dx.doi.org/10.1146/ annurev.energy.28.050302.105459

Lerman, R. I., and S. Yitzhaki. 1985. Income inequality effects by income source: a new approach and application to the United States. Review of Economics and Statistics 67(1):151-156. http:// dx.doi.org/10.2307/1928447

Lopes, L. F. G., J. M. R. dos Santos Bento, A. F. Arede Correia Cristovão, and F. O. Baptista. 2015. Exploring the effect of land use on ecosystem services: the distributive issues. Land Use Policy 45:141-149. http://dx.doi.org/10.1016/j.landusepol.2014.12.008

Martin, P. A., A. C. Newton, and J. M. Bullock. 2013. Carbon pools recover more quickly than plant biodiversity in tropical secondary forests. Proceedings of the Royal Society B: Biological Sciences 280:20132236. http://dx.doi.org/10.1098/rspb.2013.2236

McCracken, S. D., E. S. Brondizio, D. Nelson, E. F. Moran, A. D. Siqueira, and C. Rodriguez-Pedraza. 1999. Remote sensing and GIS at farm property level: demography and deforestation in the Brazilian Amazon. Photogrammetric Engineering and Remote Sensing 65:1311-1320.

McSweeney, K. 2004. Forest product sale as natural insurance: the effects of household characteristics and the nature of shock in Eastern Honduras. Society \& Natural Resources 17(1):39-56. http://dx.doi.org/10.1080/08941920490247245

Michalski, F., J. P. Metzger, and C. A. Peres. 2010. Rural property size drives patterns of upland and riparian forest retention in a tropical deforestation frontier. Global Environmental Change 20:705-712. http://dx.doi.org/10.1016/j.gloenvcha.2010.04.010

Miltner, B., and O. T. Coomes. 2015. Indigenous innovation incorporates biochar into swidden-fallow agroforestry systems in Amazonian Peru. Agroforestry Systems 89(3):409-420. http://dx. doi.org/10.1007/s10457-014-9775-5

Naughton-Treves, L., J. Alix-Garcia, and C. A. Chapman. 2011. Lessons about parks and poverty from a decade of forest loss and economic growth around Kibale National Park, Uganda. Proceedings of the National Academy of Sciences of the United States of America 108(34):13919-13924. http://dx.doi.org/10.1073/ pnas. 1013332108

Neumayer, E. 2011. Sustainability and inequality in human development. Human Development Reports. Research Paper 2011/04. United Nations Development Programme, New York, New York, USA. http://dx.doi.org/10.2139/ssrn.1905536

Padoch, C., and M. Pinedo-Vasquez. 2010. Saving slash-and-burn to save biodiversity. Biotropica 42(5):550-552. http://dx.doi. org/10.1111/j.1744-7429.2010.00681.x
Ray, D. 1998. Development economics. Princeton University Press, Princeton, New Jersey, USA.

Reardon, T., and S. A. Vosti. 1995. Links between rural poverty and the environment in developing countries: asset categories and investment poverty. World Development 23(9):1495-1506. http:// dx.doi.org/10.1016/0305-750x(95)00061-g

Reddy, S. R. C., and S. P. Chakravarty. 1999. Forest dependence and income distribution in a subsistence economy: evidence from India. World Development 27(7):1141-1149. http://dx.doi. org/10.1016/s0305-750x(99)00057-1

Ribeiro Palacios, M., E. Huber-Sannwald, L. García Barrios, F. Peña de Paz, J. Carrera Hernández, and M. G. Galindo Mendoza. 2013. Landscape diversity in a rural territory: emerging land use mosaics coupled to livelihood diversification. Land Use Policy 30:814-824. http://dx.doi.org/10.1016/j.landusepol.2012.06.007

Rudel, T. 2015. Land-use change: deforestation by land grabbers. Nature Geoscience 8:752-753. http://dx.doi.org/10.1038/ngeo2549

Ruthenberg, H. 1980. Farming systems in the tropics. Clarendon, Oxford, UK.

Schmink, M., and C. H. Wood. 1992. Contested frontiers in Amazonia. Columbia University Press, New York, New York, USA.

Stark, O., J. E. Taylor, and S. Yitzhaki. 1986. Remittances and inequality. Economic Journal 96(383):722-740. http://dx.doi. org/10.2307/2232987

Tole, L. 2004. A quantitative investigation of the population-land inequality-land clearance nexus. Population and Environment 26 (2):75-106. http://dx.doi.org/10.1007/s11111-004-0836-y

Turner, B. L., II. 2010. Land change in the southern Yucatán: case studies in land change science. Regional Environmental Change 10:169-174. http://dx.doi.org/10.1007/s10113-010-0129-1

Turner, B. L., II, S. C. Villar, D. Foster, J. Geoghegan, E. Keys, P. Klepeis, D. Lawrence, P. Macario Mendoza, S. Manson, Y. Ogneva-Himmelberger, A. B. Plotkin, D. Pérez Salicrup, R. R. Chowdhury, B. Savitsky, L. Schneider, B. Schmook, and C. Vance. 2001. Deforestation in the southern Yucatán peninsular region: an integrative approach. Forest Ecology and Management 154:353-370. http://dx.doi.org/10.1016/S0378-1127(01)00508-4

Uhl, C., and C. F. Jordan. 1984. Succession and nutrient dynamics following forest cutting and burning in Amazonia. Ecology 65 (5):1476-1490. http://dx.doi.org/10.2307/1939128

VanWey, L. K., A. O. D’Antona, and E. S. Brondízio. 2007. Household demographic change and land use/cover change in the Brazilian Amazon. Population and Environment 28:163-185. http://dx.doi.org/10.1007/s11111-007-0040-y

Walker, R. 2003. Mapping process to pattern in landscape change of the Amazonian frontier. Annals of the Association of American Geographers 93:376-398. http://dx.doi.org/10.1111/1467-8306.9302008

Wandelli, E. V., and P. M. Fearnside. 2015. Secondary vegetation in central Amazonia: land-use history effects on aboveground biomass. Forest Ecology and Management 347:140-148. http://dx. doi.org/10.1016/i.foreco.2015.03.020 
Wood, S. L. R. 2014. Land-use legacies in shifting cultivation systems of the Peruvian Amazon: the influence of land-use and landmanagement practices on forest fallow composition, function and rural livelihoods. Dissertation. McGill University, Montreal, Quebec, Canada.

Wood, S. L. R., J. M. Rhemtulla, and O. T. Coomes. 2016. Intensification of tropical fallow-based agriculture: Trading-off ecosystem services for economic gain in shifting cultivation landscapes? Agriculture, Ecosystems and Environment 215:47-56. http://dx.doi.org/10.1016/j.agee.2015.09.005 
Appendix A: Supporting Information

Table A1. Household characteristics, assets, and income, San Jose, 1994/95 and 2007.

\begin{tabular}{|c|c|c|c|c|}
\hline & \multicolumn{2}{|c|}{$\begin{array}{c}1994 / 95 \\
(1)\end{array}$} & \multicolumn{2}{|c|}{$\begin{array}{c}2007 \\
(2)\end{array}$} \\
\hline Year of household formation & 1976 & $(13.3)$ & 1983 & $(16.2)$ \\
\hline Initial land holdings (hectares) & 4.4 & $(4.9)$ & 3.9 & $(4.4)$ \\
\hline \multicolumn{5}{|l|}{ Household characteristics: } \\
\hline Age of household head (years) & 41.5 & $(13.5)$ & 46.6 & $(14.3)$ \\
\hline Household size & 5.6 & $(2.7)$ & 4.6 & $(2.0)$ \\
\hline \multicolumn{5}{|l|}{ Household assets: } \\
\hline Land holdings (hectares) & 6.7 & $(5.4)$ & 7.7 & $(4.5)$ \\
\hline$\%$ Upland $^{1}$ & $74 \%$ & & $63 \%$ & \\
\hline$\%$ Floodplain ${ }^{1}$ & $13 \%$ & & $24 \%$ & \\
\hline$\%$ Terrace $^{1}$ & $13 \%$ & & $12 \%$ & \\
\hline Non-land assets (US\$) $)^{2}$ & 108 & $(151)$ & 174 & $(246)$ \\
\hline \multicolumn{5}{|l|}{ Household upland use: } \\
\hline \% Cropping ${ }^{3}$ & $11 \%$ & & $12 \%$ & \\
\hline$\%$ Orchard $^{3}$ & $38 \%$ & & $25 \%$ & \\
\hline$\%$ Fallow $^{3}$ & $51 \%$ & & $63 \%$ & \\
\hline Orchard age (years) ${ }^{4}$ & 18.7 & (8.8) & 9.3 & $(5.2)$ \\
\hline Fallow duration (years) ${ }^{4}$ & 11.7 & $(4.6)$ & 14.7 & $(10.1)$ \\
\hline \multicolumn{5}{|l|}{ Household income: } \\
\hline Income (US\$) & 3195 & (1852) & 4416 & $(2252)$ \\
\hline Crop & $61 \%$ & & $22 \%$ & \\
\hline Fishing & $9 \%$ & & $38 \%$ & \\
\hline Charcoal & $17 \%$ & & $26 \%$ & \\
\hline Other ${ }^{5}$ & $14 \%$ & & $14 \%$ & \\
\hline No. observations & 32 & & 48 & \\
\hline No. observations (income) & 19 & & 24 & \\
\hline
\end{tabular}

${ }^{1}$ Former pasture as another land type is not shown.

${ }^{2} \mathrm{n}=19$ in 1994/95, $\mathrm{n}=46$ in 2007

${ }^{3}$ Unknown land use is ignored.

${ }^{4}$ Based on plots with complete land cover history using plot size as weights. No. of observations vary. ${ }^{5}$ Other income includes handicrafts, hunting, livestock, wage labor, non-timber forest extraction, and shop.

Notes - Household means are shown. Standard deviations are in parentheses. 3.13 Sole/USD(2007). 
Figure A1.1. Gini decomposition by mode of land acquisition for all lands (A) and upland only (B), 19802007.

\section{A. All lands}

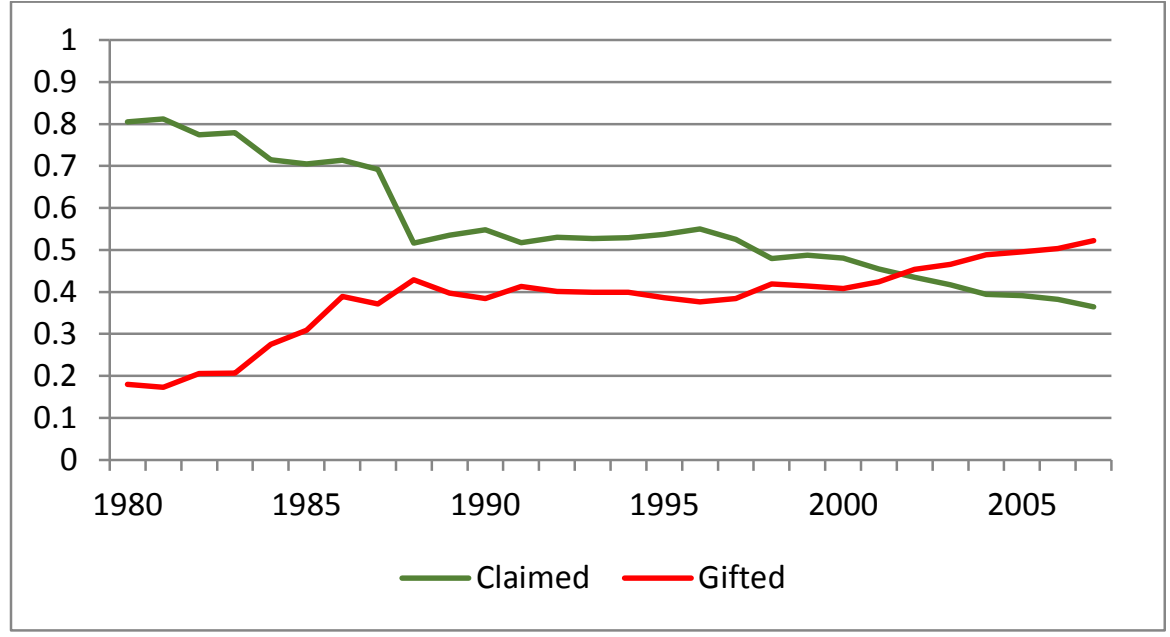

\section{B. Upland}

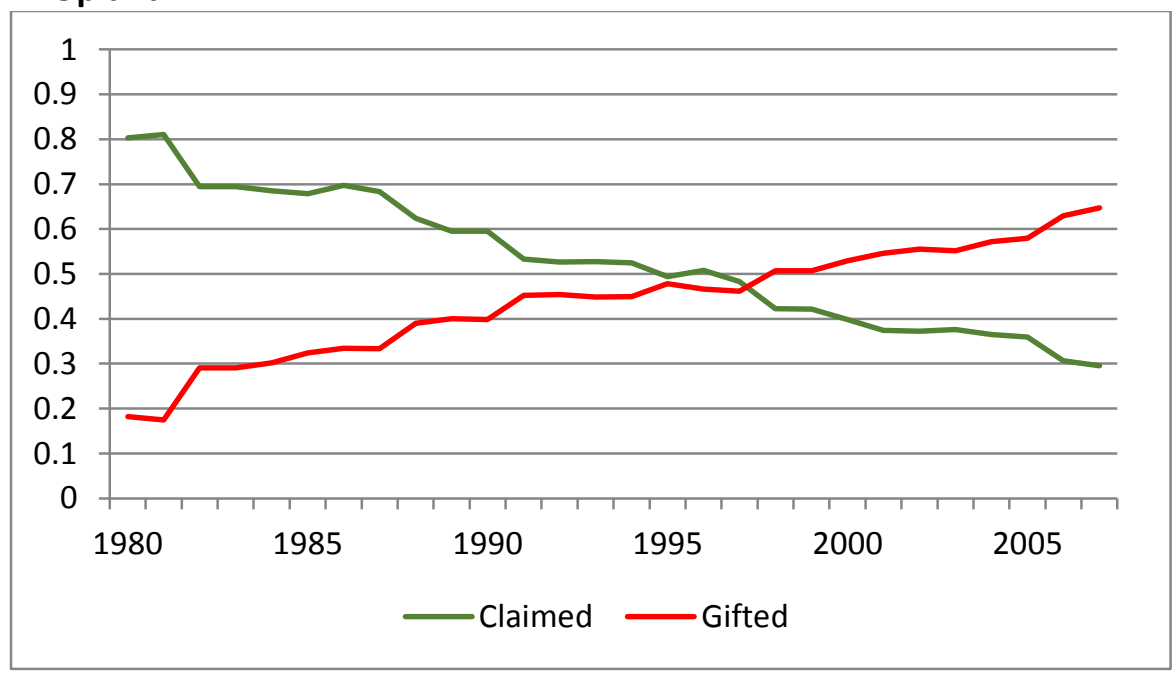


Figure A1.2. Gini decomposition by mode of acquisition of upland fallows and orchards, 1980-2007.

A. Fallows

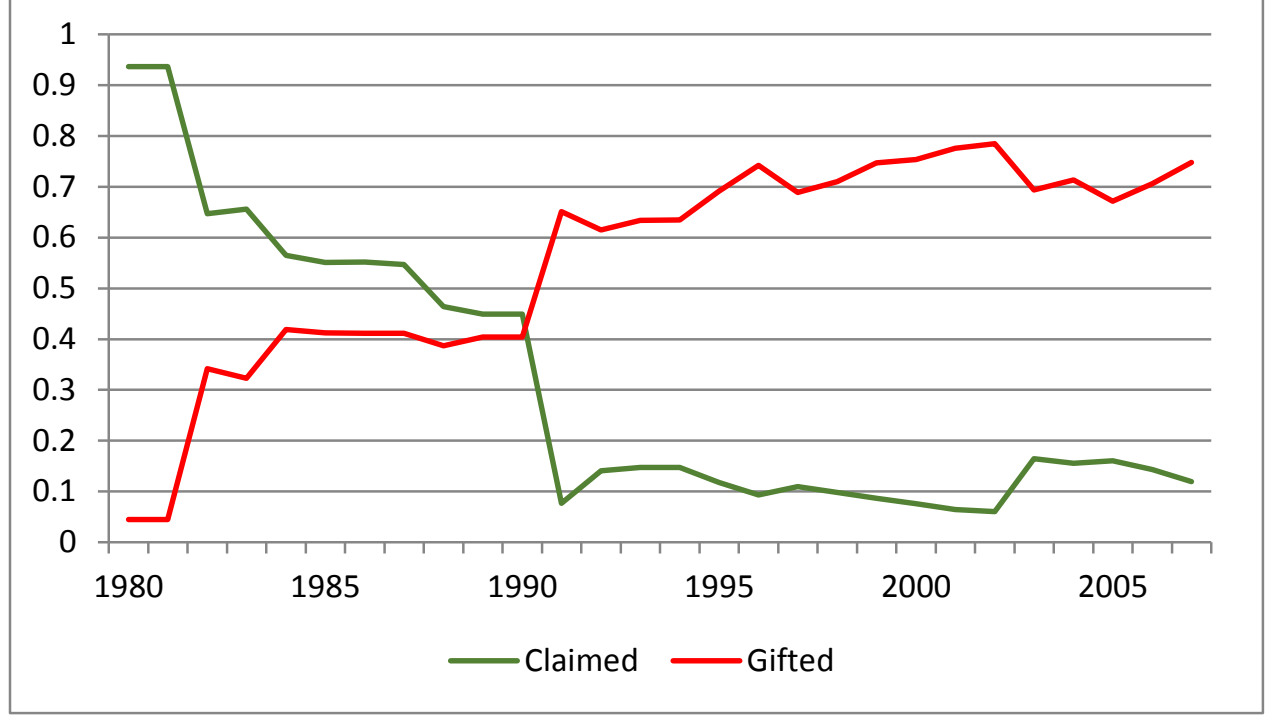

\section{B. Orchards}

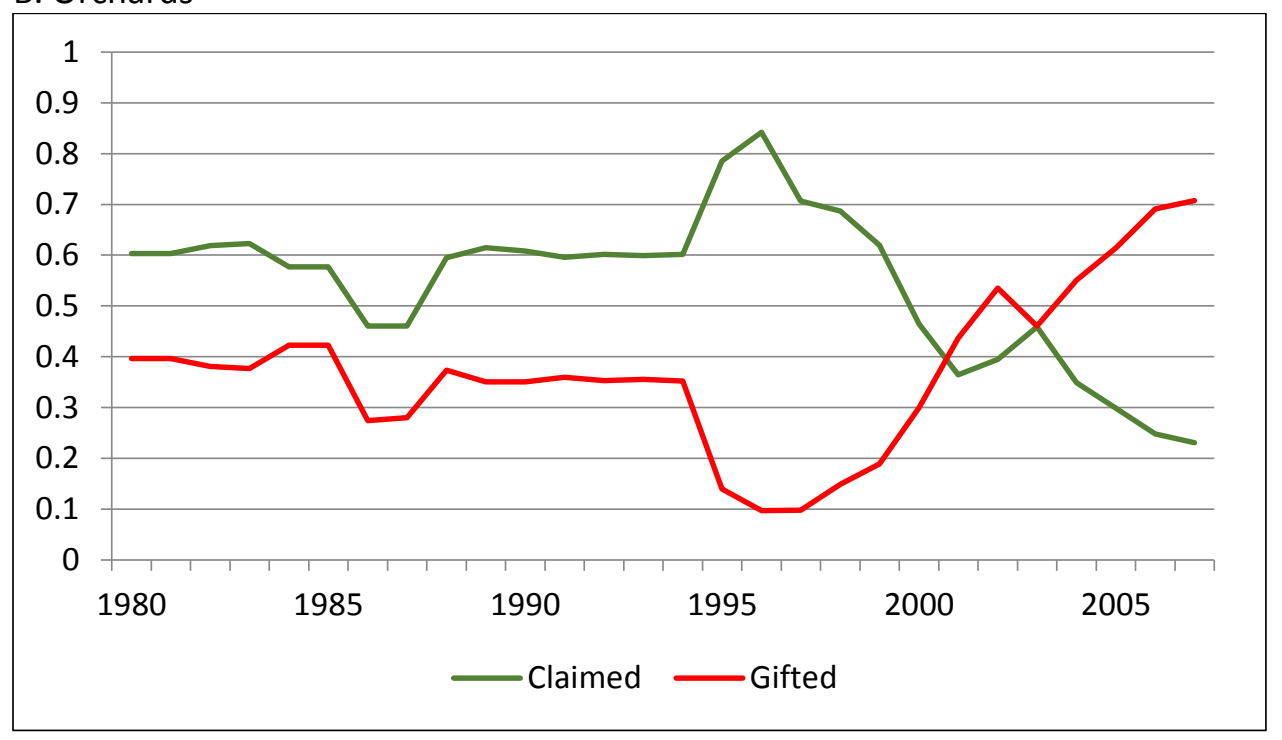


Figure A1.3. Total land holdings by household initial land endowment, San Jose 1980-2007.

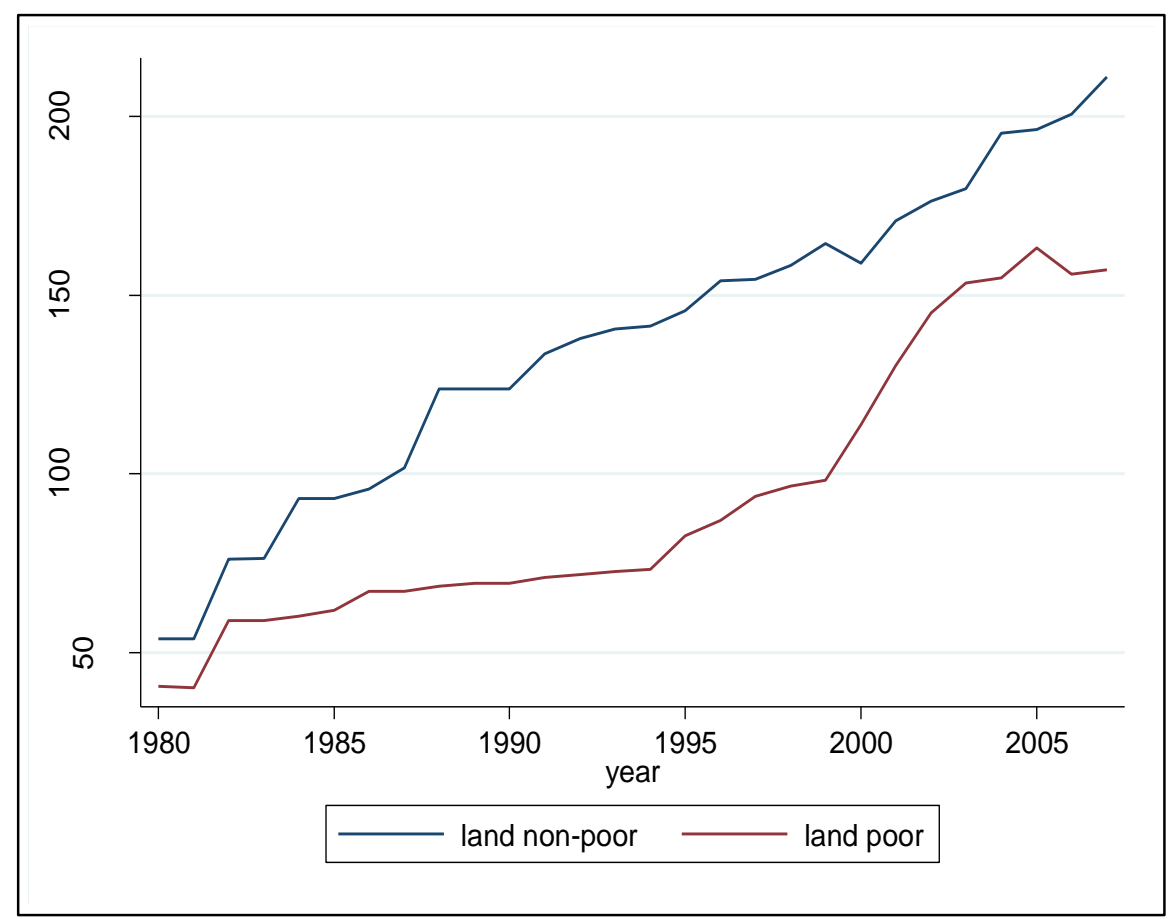

Notes: The median initial land holding was used as the fixed breakpoint between initial poor and nonpoor households in lieu of a natural breakpoint in the data. Initial land holdings at the time of household formation are used to define initially land poor/nonpoor households. 
Figure A1.4. Nonparametric density estimates for orchard age and fallow duration for initial land nonpoor and poor households, San Jose, 1995-2007.

A) Orchard age

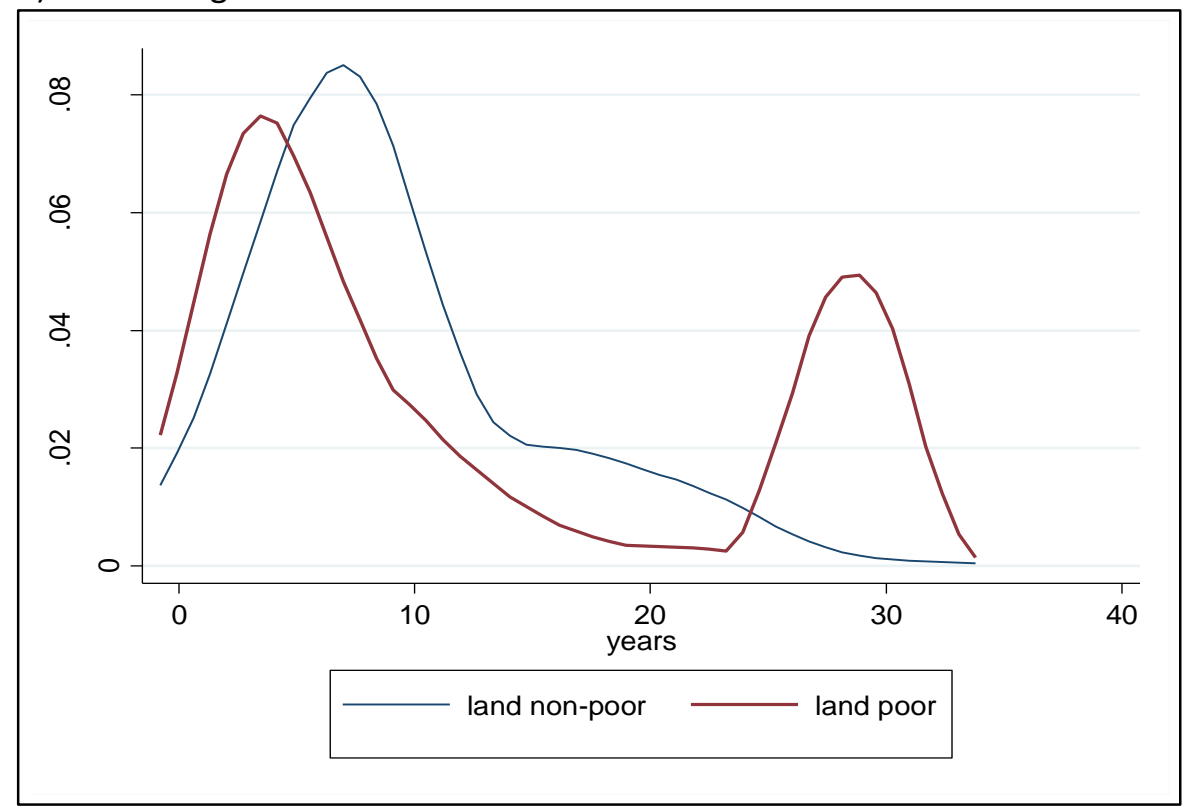

B) Fallow duration

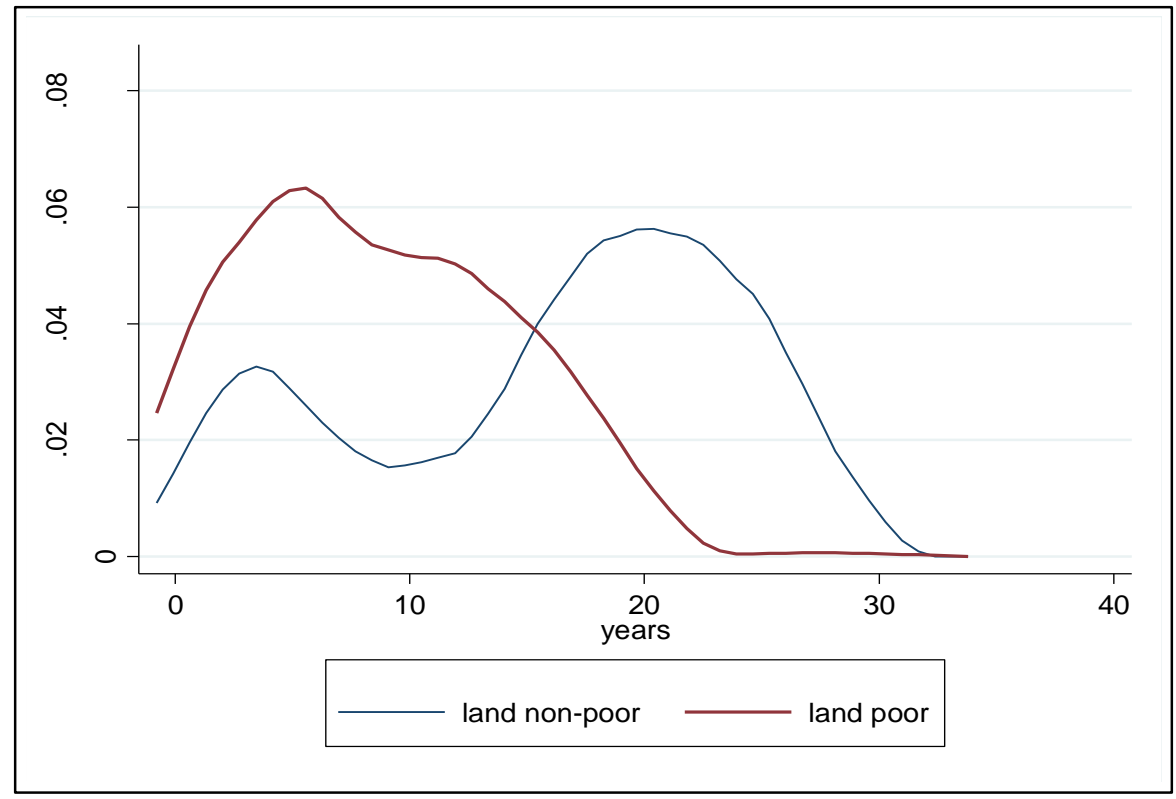

Notes: The median initial land holding was used as the fixed breakpoint between initial poor and nonpoor households in lieu of a natural breakpoint in the data. Initial land holdings at the time of household formation are used to define initially land poor/non-poor households. 